\title{
Dormancy overcoming in seeds of cajá-manga (Spondias dulcis)
}

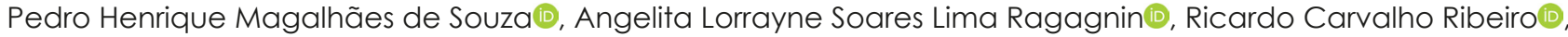

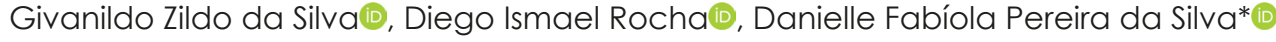

Federal University of Jataí, Jataí, Brazil

*Corresponding author, e-mail: daniellefpsilva@ufg.br

\begin{abstract}
The propagation of 'cajá-manga' (Spondias dulcis) is usually performed by seeds. The presence of dormancy is an obstacle for seedling production and the commercial use of its main product, the fruit. This research aimed to evaluate the use of phytoregulators associated with the scarification of the distal region of the embryo in dormancy overcoming and in the standardization of germination of 'cajá-manga' seedlings. Endocarps extracted from fruits of six matrices were subjected to the following treatments: control (T1), mechanic scarification in the distal region of the embryonic axis (T2); all following treatments involved scarification and imbibition in a solution of: water for $6 \mathrm{~h}$ (T3); $\mathrm{GA}_{3}\left(750 \mathrm{mgL}^{-1}\right)$ for $6 \mathrm{~h} \mathrm{(T4);} \mathrm{GA}_{3}$ (350 $\mathrm{mg} \mathrm{L}^{-1}$ ) for 12h (T5); Cytokinin (750 $\mathrm{mg} \mathrm{L}^{-1}$ ) for $6 \mathrm{~h} \mathrm{(T6);} \mathrm{Cytokinin} \mathrm{(350} \mathrm{mg} \mathrm{L}^{-1}$ ) for 12h (T7); $\mathrm{GA}_{3}$ and Cytokinin (750 $\mathrm{mg} \mathrm{L}^{-1}$ ) for $6 \mathrm{~h}$ (T8); and $\mathrm{GA}_{3}$ and Cytokinin sowing 25 endocarps in expanded polystyrene trays using a washed sand substrate. The following variables were evaluated: emergence, first emergence count, emergence speed index, mean emergence time, shoot and root length of seedlings, and relative emergence frequency. The experimental design was in randomized blocks, with 9 treatments and four replications consisting of 25 endocarps each. The data obtained were subjected to the F Test at a $1 \%$ level of probability, as well as to the Scott-Knott method. The use of mechanic scarification in the opposite region of the embryonic axis, followed by the imbibition in a solution of gibberellin + cytokinin at the concentration of $350 \mathrm{mgL}^{-1}$ for 12 hours is promising for dormancy overcoming in seeds of Spondias dulcis.
\end{abstract}

Keywords: Spondias dulcis, Cyłokinin, Gibberellin, Seedlings

\section{Introduction}

Within the genus Spondias, fours species are economically important in tropical America: S. dulcis, S. mombin, S. purpurea, and S. tuberosa, which are cultivated and, therefore, are not at risk of extinction, although their genetic diversity can be compromised due to habitat destruction (Mitchell \& Daly, 2015). However, the implantation of production fields through seeds is usually hindered by dormancy (Moura et al., 2013; Martins et al., 2019).

Dormancy provides slow and uneven germination, as already noted by other authors for other species of the same genus, such as Spondias mombin (Martins et al., 2019) and as reported for native trees (Matos \& Ataíde, 2015). Consequently, especially in this genus, combinational dormancy occurs. The first type of dormancy is a physical barrier imposed by the endocarp that acts as a limiting factor, promoting mechanical resistance to embryo expansion, as well as gas exchange. The second, of a physiological nature, requires the use of phytoregulators to overcome this dormancy, normally gibberellic acid $\left(\mathrm{GA}_{3}\right)$ (Carvalho \& Nakagawa, 2012; Ferreira et al., 2016; Martins et al., 2019).

Mechanical scarification is highlighted among the methods for overcoming physical dormancy, usually performed with a cut in the distal region of the hilum but not reaching the embryonic axis, causing disruption or weakening of the integument and allowing germination (Carvalho \& Nakagawa, 2012; Oliveira et al., 2018). This method was successfully employed in $S$. mombin (Martins et al., 2019). Physiological dormancy can be attributed to hormones that inhibit germination (Carvalho \& Nakagawa, 2012; Miransari \& Smith, 2014). There are other hormones, among them cytokinin, whose efficiency in germination is still little know; however, it is already understood that cytokinin promotes cell 
division and, associated with gibberellin, they constitute essential substances that promote germination and the enzymatic process when these are blocked by inhibitors of physiological dormancy (Miransari \& Smith, 2014; Piccoloto et al., 2007; Taiz et al., 2017).

It is emphasized that, in nature, dormancy is one of the phenomena that guarantee production over time. For seedling producers, however, it constitutes an obstacle since the seeds are subjected to adverse conditions due to slow germination, also resulting in uneven seedlings (Carvalho \& Nakagawa, 2012; Costa et al., 2010).

For dormancy overcoming in 'cajá-manga' seeds, studies are still incipient. Germination in this species is slow and uneven, and the use of dormancy overcoming methods, such as the application of phytoregulators, can assist in obtaining quality seedlings and helping in the domestication process of this species (Carvalho \& Nakagawa, 2012; Ferreira et al., 2016; Matos \& Ataíde. 2015; Rocha et al., 2019).

Thus, the present work aimed to evaluate the use of phytoregulators (gibberellins and cytokinins) associated with the scarification of the distal region of the embryo in dormancy overcoming and standardization of seeds of 'cajá-manga'.

\section{Material and Methods}

The 'cajá-manga' fruits were harvested in the natural vegetation of the municipality of Jataí, state of Goiás, Brazil, in February 2019, from six matrices with a minimum distance of $3.5 \mathrm{~km}$ from each other (Table 1).

Table 1. Georeferencing of and dimensions of height $(\mathrm{H})$ and Diameter at Breast Height (DBH) of matrices of Spondias dulcis in the Jataí-GO region.

\begin{tabular}{cccc}
\hline Matrices & Geographic Coordinates & $\mathrm{DBH}(\mathrm{cm})$ & $\mathrm{H}(\mathrm{m})$ \\
\hline M1 & $17^{\circ} 52^{\prime} 47^{\prime \prime} \mathrm{S} 51^{\circ} 44^{\prime} 06^{\prime \prime} \mathrm{O}$ & 62.2 & 14.5 \\
M2 & $17^{\circ} 54^{\prime} 55^{\prime \prime} \mathrm{S} 51^{\circ} 44^{\prime} 05^{\prime \prime} \mathrm{O}$ & 65.0 & 18.5 \\
M3 & $17^{\circ} 53^{\prime} 51^{\prime \prime} \mathrm{S} 51^{\circ} 43^{\prime} 24^{\prime \prime} \mathrm{O}$ & 60.4 & 16.0 \\
M4 & $1^{\circ} 51^{\prime} 39^{\prime \prime} \mathrm{S} 51^{\circ} 43^{\prime} 45^{\prime \prime} \mathrm{O}$ & 73.0 & 22.0 \\
M5 & $17^{\circ} 53^{\prime} 06^{\prime \prime} \mathrm{S} 51^{\circ} 43^{\prime} 32^{\prime \prime} \mathrm{O}$ & 64.0 & 15.0 \\
M6 & $17^{\circ} 53^{\prime} 57^{\prime \prime} \mathrm{S} 51^{\circ} 44^{\prime} 05^{\prime \prime} \mathrm{O}$ & 60.2 & 18.0 \\
\hline
\end{tabular}

Afterward, the fruits were stored in plastic boxes $(55 \times 36 \times 31 \mathrm{~cm})$ and transported to the Agronomic Research Center of the Federal University of Jataí (UFJ).

For the extraction of the endocarp, the fruits were immersed and sprayed with water and sanitized with a $2 \%$ sodium hypochlorite solution for 15 minutes. The fruits were subjected to endocarp extraction under running water with the aid of a knife, as recommended for the genus Spondias (Brasil, 2013). The endocarps that contained real seeds were denominated seeds, as described in the normative instructions for forest seeds analysis (Brasil, 2013).
The extracted endocarps were subjected to the treatments according to Table 2.

Table 2. Treatments used for dormancy overcoming in seeds of 'cajá-manga' removed from fruits of different matrices of Jataí-GO.

\section{Treatments}

T1. Control: without dormancy overcoming treatment

T2. Scarification in the distal region

T3. $12+$ Imbibition in water for $6 \mathrm{~h}$

T4. $\mathrm{T} 2+$ Imbibition in $\mathrm{GA}_{3}\left(750 \mathrm{mg} \mathrm{L}^{-1}\right)$ for $6 \mathrm{~h}$

T5. $\mathrm{T} 2+$ Imbibition in $\mathrm{GA}_{3}\left(350 \mathrm{mg} \mathrm{L}^{-1}\right)$ for $12 \mathrm{~h}$

T6. T2 + Imbibition in Cytokinin (750 $\left.\mathrm{mg} \mathrm{L}^{-1}\right)$ for $6 \mathrm{~h}$

T7. T2 + Imbibition in Cytokinin (350 $\left.\mathrm{mg} \mathrm{L}^{-1}\right)$ for $12 \mathrm{~h}$

T8. $\mathrm{T} 2+$ Imbibition in $\mathrm{GA}_{3}$ and Cytokinin $\left(750 \mathrm{mg} \mathrm{L}^{-1}\right)$ for $6 \mathrm{~h}$

T9. T2 + Imbibition in $\mathrm{GA}_{3}$ and Cytokinin $\left(350 \mathrm{mg} \mathrm{L}^{-1}\right)$ for $12 \mathrm{~h}$

For the treatments with scarification in the distal region, a 6-inch bench grinder was used (152 $\mathrm{mm}$ of diameter). After the treatments, four blocks with 25 endocarps were individually sown in expanded polystyrene trays ( $35 \times 25 \times 5 \mathrm{~cm}$ ) containing a washed sand substrate with $60 \%$ retention capacity, which was previously sieved in a $0.8 \mathrm{~mm}$ mesh sieve and sterilized in a forced-air circulation oven at $200^{\circ} \mathrm{C}$ for two hours (Brasil, 2013).

The experiment was maintained in a plant nursery with an automatic sprinkler irrigation system programmed to be triggered at the beginning and end of the day for an irrigation shift of 40 minutes, evaluating the following characteristics:

Seedling emergence - the most vigorous normal seedlings emerged were evaluated at 60 days, considering that the emergence of more than one seedling per endocarp may occur.

First emergence count - accounting of the most vigorous normal seedlings when reaching $50 \%+1$ of final emergence.

Emergence speed index (ESI) - performed by counting the most vigorous normal seedlings every five days during 60 days; the data were then subjected to the formula proposed by Maguire (1962).

Mean emergence time (MET) - registered from five to 60 days; the data were subjected to the formula described by Santana \& Ranal (2004), with the results expressed in days after sowing.

Shoot and root length of seedlings - assessed by measuring the shoot part, from the base to the insert of the cotyledon, and the main root, from the hood to the base of the most vigorous normal seedling.

Relative emergence frequency (Ref) - the counts from five to 60 days were subjected to the formula described by Santana \& Ranal (2004).

A completely randomized block design was 
used in the experiment, with treatments distributed into four blocks, with 25 endocarps in each portion. The data obtained were subjected to the normality of data and error homogeneity tests; the F-test at $1 \%$ of probability was also employed, and the Scott-Knott method was used for the comparison of means, using the Rbio software, version 119:06/06/2019.

\section{Results and Discussion}

There was an effect of the treatments on the variables of emergence, first emergence count, and emergence speed index (Table 3), with no difference being observed for the mean emergence time and remaining measurements in the obtained seedlings.

The scarification at the distal region, followed by imbibition in $\mathrm{GA}_{3}$ and Cytokinin $\left(350 \mathrm{mgL}^{-1}\right.$ ) for 12 hours (treatment 9), was efficient for overcoming dormancy in 'cajá-manga' seeds (Table 4). This treatment obtained $63 \%$ of seedling emergence at 60 days after sowing (d.a.s.) and an emergence speed index of 3.41, values higher than those of other treatments. It is emphasized that, in comparison with the control, this difference was three times higher, demonstrating its efficiency.

Table 3. Summary of the analysis of variance of the data of emergence (E), first emergence count (FEC), emergence speed index (ESI), mean emergence time (MET), shoot length (SL), and root length (RL) of 'cajá-manga' seedlings produced from seeds with different dormancy overcoming treatments.

\begin{tabular}{|c|c|c|c|c|c|c|}
\hline \multirow{2}{*}{ Source of variation } & \multicolumn{6}{|c|}{ Mean squares } \\
\hline & $E$ & FEC & ESI & MET & SL & $\mathrm{RL}$ \\
\hline Treatments & $1001.00 * *$ & $44.45^{* *}$ & $2.98^{* *}$ & $2.81 \mathrm{ln} . \mathrm{s}$ & $21.12 n . s$ & 5.93n.s \\
\hline Blocks & 167.7 & 28.89 & 1.04 & 5.40 & 62.65 & 11.61 \\
\hline Residues & 134.70 & 15.56 & 0.35 & 4.11 & 31.99 & 4.63 \\
\hline CV\% & 38.69 & 64.54 & 38.02 & 4.73 & 16.01 & 21.40 \\
\hline
\end{tabular}

Table 4. Emergence (E), first emergence count (FEC), and emergence speed index (ESI) of 'Cajá-manga' seedlings produced from seeds with different dormancy overcoming treatments.

\begin{tabular}{|c|c|c|c|}
\hline Treatments & $\begin{array}{l}\mathrm{E} \\
\%\end{array}$ & $\begin{array}{c}\text { FEC } \\
\text { (days) }\end{array}$ & ESI \\
\hline T1. Control: without treatment for dormancy & $21 \mathrm{~d}$ & $5 b$ & $1.06 \mathrm{C}$ \\
\hline T2. Scarification in the distal region & $31 \mathrm{c}$ & $4 \mathrm{~b}$ & $1.59 \mathrm{~b}$ \\
\hline T3. T2 + Imbibition in water for $6 \mathrm{~h}$ & $20 d$ & $4 \mathrm{~b}$ & $0.95 \mathrm{c}$ \\
\hline T4. T2 + Imbibition in $\mathrm{GA}_{3}\left(750 \mathrm{mg} \cdot \mathrm{L}^{-1}\right)$ for $6 \mathrm{~h}$ & $10 \mathrm{~d}$ & $4 \mathrm{~b}$ & $0.57 \mathrm{c}$ \\
\hline T5. T2 + Imbibition in $\mathrm{GA}_{3}\left(350 \mathrm{mg} . \mathrm{L}^{-1}\right)$ for $12 \mathrm{~h}$ & $33 \mathrm{c}$ & $5 \mathrm{~b}$ & $1.97 \mathrm{~b}$ \\
\hline T6. T2 + Imbibition in Cytokinin (750 mg. $\left.\mathrm{L}^{-1}\right)$ for $6 \mathrm{~h}$ & $17 \mathrm{~d}$ & $3 b$ & $0.85 \mathrm{c}$ \\
\hline T7. T2l + Imbibition in Cytokinin (350 mg. $\left.\mathrm{L}^{-1}\right)$ for $12 \mathrm{~h}$ & $43 \mathrm{~b}$ & $10 a$ & $2.09 \mathrm{~b}$ \\
\hline T8. T2 + Imbibition in $\mathrm{GA}_{3}$ and Cytokinin (750 mg. $\mathrm{L}^{-1}$ ) for $6 \mathrm{~h}$ & $32 \mathrm{c}$ & $7 \mathrm{~b}$ & $1.65 \mathrm{~b}$ \\
\hline T9. T2 + Imbibition in $\mathrm{GA}_{3}$ and Cytokinin $\left(350 \mathrm{mg}^{-1}\right.$ ) for $12 \mathrm{~h}$ & $63 \mathrm{a}$ & $13 a$ & $3.41 \mathrm{a}$ \\
\hline
\end{tabular}

When comparing the values of emergence (63\%) and mean emergence time around 43 days, even though there is no statistical difference (Tables 3 and 4), the results in the literature ensure how much the treatment applied in this work was significant. Martins et al. (2019), evaluating S. mombin, verified a $68 \%$ emergence and a mean emergence time of 273 days after sowing for medium-sized endocarps with beige color and with subjected to mechanic scarification.

At 18 days after sowing, the first germination count resulted in $13 \%$ when performing the scarification of the distal region followed by imbibition in $\mathrm{GA}_{3}$ and Cytokinin (350 $\mathrm{mg} \mathrm{L}^{-1}$ ) for 12 hours (treatment 9), not differing for this variable from the treatment subjected to scarification followed by imbibition in Cytokinin (350 $\mathrm{mg} \mathrm{L}^{-1}$ ) for 12 hours (treatment 7) since each obtained 10 seedlings. Martins et al. (2019), studying the germination of cajá (S. mombin) seeds, obtained first germination count values of $28 \%$; however, this count occurred at 180 days after sowing.

The application of phytoregulators on dormancy overcoming or standardization of germination was performed. Majidi at al. (2016) recommend that the application of the $\mathrm{GA}_{3}$, indoleacetic acid (IAA), and kinetin phytoregulators aid in overcoming dormancy and promote quickgermination in Hordeumspontaneum. In the same way, but not so equitably, the use of an association of phytoregulators, such as in the present research, has also been used. Ferreira et al. (2016) efficiently applied dormancy overcoming for seeds of Annona purpurea (chincuya) and A. macroprophyllata (papausa) through soaking in a $\mathrm{GA}_{4+7}+\mathrm{BA}$ (6-benzyladenine) mixture for 96 hours. This combination of phytoregulators was also employed by Beraud et al. (2016) for Ugni molinae Turcz, a fruit species native to Chile.

There is a scarcity of studies evaluating the effect 
of cytokinin on Spondias spp. Melo et al. (2012), when evaluating the effect of gibberellin, kinetin, and ethylene, verified no differences in seedling emergence for $S$. tuberosa, either with or without mechanic scarification. It is known that cytokinins modulate cell division and differentiation (Rajesh et al., 2019; Taiz et al., 2017). However, the effect of cytokinin on dormancy overcoming has also been checked in another species, for which Lee et al. (2018) found that kinetin had a significant effect on germination promotion and in dormancy breaking of seeds of Panax ginseng (ginseng), although a short period of cold stratification is still necessary. For Arabidopsis, it was verified that among the functions of cytokinin, there is the control of seed size, including embryo growth, endosperm and seed coating (Mansfield \& Bowman, 1993). Miransari \& Smith (2014) affirm that cytokinin and its negative interaction with $A B A$ can positively regulate the seed germination and interrupt the seed dormancy.

The action of gibberellins in seed germination is already a fact in the literature as they act in germination promotion and the activation of vegetative growth in the embryo through the mobilization of reserves (Takata et al., 2014; Taiz et al., 2017). Taiz et al. (2017) still reported that the capacity of controlling metabolic processes in plants, from germination to growth, is promoted by gibberellins, through the increase in the number and length of cells.

For treatment 2 , the reduction of the physical barrier with mechanic scarification only was not enough to overcome dormancy in 'cajá-manga', evidencing the combined dormancy of these seeds, that is, a physical barrier imposed by the endocarp as well as a physiological barrier, probably constituted by inhibitory substances that prevent the germination process. This fact has already been confirmed in other Spondias species, such as by Melo et al. (2012) in seeds of S. tuberosa and by Martins et al. (2019) in S. mombim.

When the imbibition for six hours was employed, even in treatment 8 , which was very similar to the best treatment, a little effect of the treatment was verified on dormancy overcoming. The interval of six hours of imbibition was probably not enough to overcome the physical barrier of the endocarp as well as to start the seed imbibition process and activation of phytoregulators, even if these were used in higher concentrations (750 $\mathrm{mgL}^{-1}$ ) in these treatments.

Figure 1 depicts the relative emergence frequency of 'cajá-manga' seedlings, in which it is possible to observe that, over time, seedling emergence reaches a maximum point, declines, and go back up; the frequency polygons present a polymodal frequency, with heterogeneous emergence in more than two peaks (Santana \& Ranal, 2004). Based on the graphics, it is possible to affirm that the emergence in this species is not yet perfectly synchronized, even with the efficient treatment, spreading out over the time (Oliveira et al., 2017).
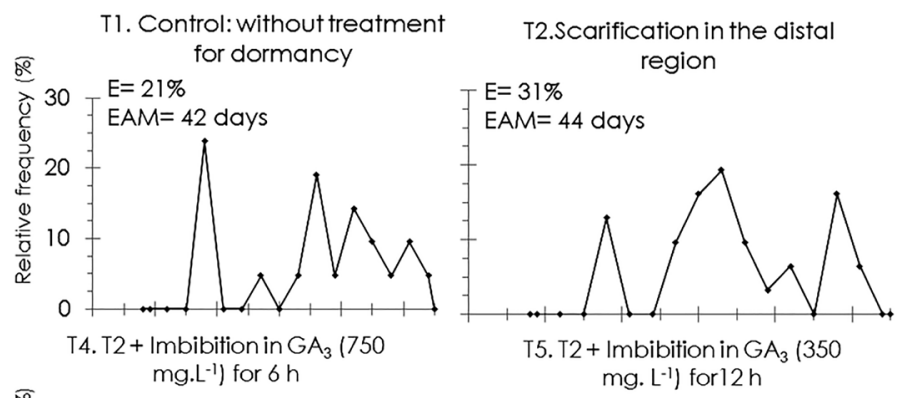
T3. T2 + Imbibition in water for $6 \mathrm{~h}$

$E=20 \%$

$\mathrm{EAM}=43$ days

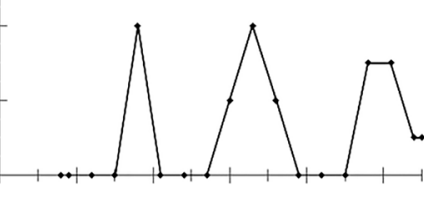

T6. T2 + Imbibition in Cytokinin (750 mg. $\mathrm{L}^{-1}$ ) for $6 \mathrm{~h}$
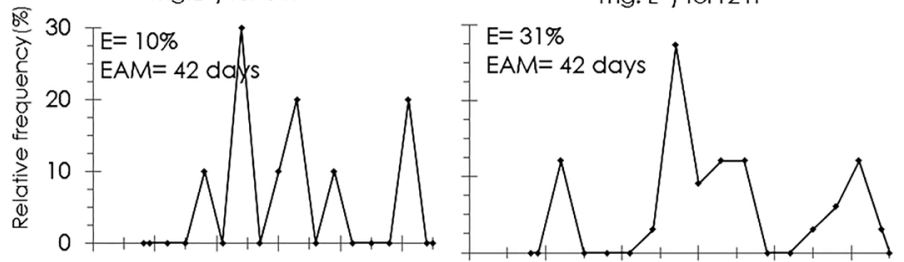

T7. T2 + Imbibition in Cytokinin (350 $\mathrm{mg}^{-1} \mathrm{~L}^{-1}$ ) for $12 \mathrm{~h}$

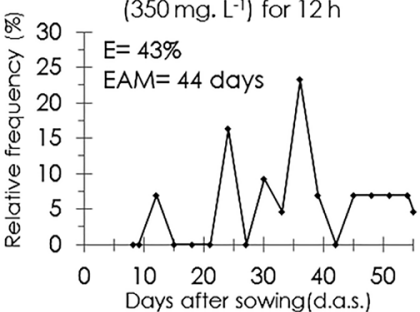

T8. $\mathrm{T} 2+$ Imbibition in $\mathrm{GA}_{3}$ and Cytokinin (750 mg. $\left.\mathrm{L}^{-1}\right)$ for $6 \mathrm{~h}$

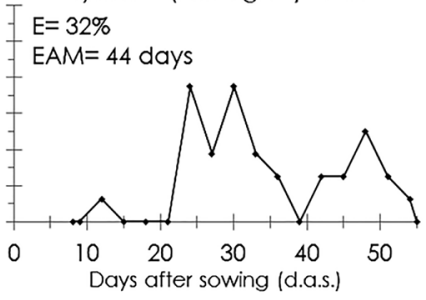

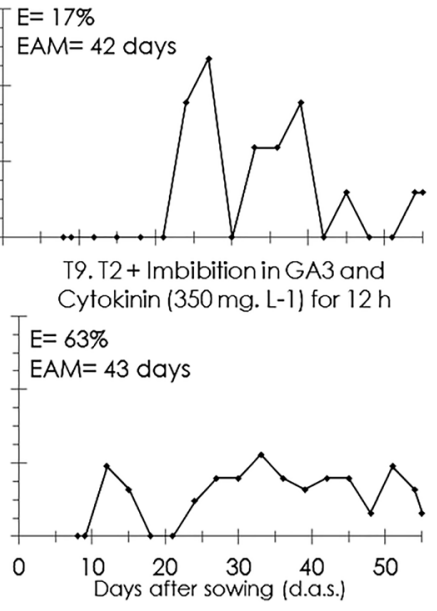

Figure 1. Distribution of the relative emergence frequency of 'cajá-manga' seedlings produced from seeds subjected to different dormancy overcoming treatments ( $E=$ seedling emergence percentage; $\mathrm{EAM}=$ mean emergence time). 
The beginning of seedling emergence occurred around eleven days after sowing, except for the control treatment and for treatments T2, T3, and T6, whose emergence began 20 days after seeding. This period was similar to that reported by Melo et al. (2012) for the seedling emergence of Spondias tuberosa, in which the seedling emerged at nine days.

For the mean emergence time, it was verified that there was no difference between the evaluated treatments since the frequency distributions showed that the mean emergence time ranged between 42 and 44 days (Table 3, Figure 1). There was no displacement of the polygon since the mean times were similar, implying that, even uneven, there was no displacement of the polygonal line to the right or to the left of the mean emergence time, that is, there was no delay on the seedling emergence process (Berger, 2014).

It should be noted that, still in Figure 1, treatment 9 (scarification followed by imbibition in $\mathrm{GA}_{3}$ and Cytokinin (350 $\mathrm{mg} \mathrm{L}^{-1}$ ) for 12 hours) revealed to be promising in the dormancy overcoming of 'cajá-manga', promoting a seedling emergence of $63 \%$ and presenting a different behavior from the others, probably for being the only treatment that increased the emergence speed, with an index of 3.41 (Table 3).

\section{Conclusions}

The use of mechanic scarification in the opposite region of the embryonic axis, followed by the imbibition in a solution of gibberellin + cytokinin phytoregulators in the concentration of $350 \mathrm{mg} \mathrm{L}^{-1}$, for 12 hours, is promising to overcome dormancy in 'cajá-manga' seeds.

\section{Acknowledgements}

The authors thank the Coordination for the Improvement of Higher Education Personnel (CAPES) and the National Council for Scientific and Technological Development (CNPq) for their financial support.

\section{References}

Beraud, M.R., Vásquez, N.H., Durán, X.A., Pérez, J.T. Marambio, V.L., Rubio, C.C. 2016. Efectos del ácido giberélico, bencilaminopurina y fluridona en la germinación in vitro de Ugni molinae Turcz. (Myrtaceae). Gayana. Botánica 73: 77-84.

Berger, A.P.A., Ranal, M.A., Santana, D.G. 2014. Variabilidade na dormência relativa dos diásporos de Lithraea molleoides (Vell.) Eng. Ciência Florestal 24: 1-13.

Brasil, Ministério da Agricultura, Pecuária e Abastecimento. 2013. Instruções para análise de sementes de espécies florestais. Mapa/ACS, Brasília, Brazil. 98 p.

Carvalho, N.M., Nakagawa, J. 2012. Sementes: ciência, tecnologia e produção. FUNEP, Jaboticabal, Brazil. 590 p.

Costa, P.A., Lima, A.L.S., Zanella, F., Freitas, H. 2010. Quebra de dormência em sementes de Adenanthera pavonina L. Pesquisa agropecuária tropical 40: 83-88.

Ferreira, G., De-La-Cruz-Chacon, I., Gonzalez-Esquinca, A.R. 2016. Overcoming seed dormancy in Annona macroprophyllata and Annona purpurea using plant growth regulators. Revista Brasileira de Fruticultura 38: $1-10$.

Lee, J.W., Jo, I.H., Kim, J.U., Hong, C.E., Kim, Y.C., Kim, D.H., Park, Y.D. 2018. Improvement of seed dehiscence and germination in ginseng by stratification, gibberellin, and/or kinetin treatments. Horticulture, Environment, and Biotechnology 59: 293-301.

Maguire, J.D. 1962. Speed of germination-aid in selection and evaluation for seedling emergence and vigor. Crop Science 2: 176-177.

Majidi, M., Taghvaei, M., Heidari, G., Edalat, M., Emam, Y. 2016. Dormancy release of wild barley seed germination by using plant growth regulators. Environmental and Experimental Biology 14: 145-150.

Mansfield, S.G., Bowman, J. 1993. Embryogenesis in Arabidopsis. In: Bowman, J. (Ed.). An Atlas of Morphology and Development. Springer-Verlag, Berlin, Germany. p. 349-362.

Martins, C.C., Silva, G.Z. da, Durigan, L.D., Vieira, R.D. 2019. Pregerminative treatments of yellow mombin (Spondias mombin L.) seeds. Ciência Florestal 29: 363-370.

Matos, A.C.B., Ataíde, G.D.M. 2015. Physiological, physical, and morpho-anatomical changes in Libidibia ferrea ((Mart. ex Tul.) LP Queiroz) seeds after overcoming dormancy. Journal of Seed Science 37: 26-32.

Melo, A.P.C., Seleguini, A., Castro, M.N., Andrade, F.M., Silva, J.M.G., Haga, K.I. 2012. Superação de dormência de sementes e crescimento inicial de plântulas de umbuzeiro. Semina: Ciências Agrárias 33: 1343-1349.

Miransari, M., Smith, D.L. 2014. Plant hormones and seed germination. Environmental and Experimental Botany 99: 110-121.

Mitchell, J.D., Daly, D.C. 2015. A revision of Spondias L. (Anacardiaceae) in the Neotropics. PhytoKeys 55: 1-92.

Moura, F.T., Silva, S.M., Schunemann, A.P.P., Martins, L.P. 2013. Frutos do umbuzeiro armazenados em diferentes estádios de maturação. Revista Ciência Agronômica 47:131-133.

Oliveira, F.S. da, Silveira, L.M., Torres, S.B., Costa, F.M.C.D. da, Nunes, M.C.C., Senna, J.S. de, Neto, S. 2018. Dormancy breaking in seeds of different accessions of Luffa cylindrica Roemer. Comunicata Scientiae 9: 596602.

Oliveira, J.D. de, Silva, J.B. da, Alves, C.Z. 2017. Tratamentos para incrementar, acelerar e sincronizar a emergência de plântulas de mucuna-preta. Revista 
Ciência Agronômica, 48: 531-539.

Picolotto, L., Bianchi, V.J., Fachinello, J.C. 2007. Ação de giberelinas e citocininas na germinação de sementes de pessegueiro. Scientia Agraria 8: 225-232.

Rajesh, K.J., Mulam, P., Vidhesh, K. 2019. Elucidation of seed dormancy and phytohormones by germination after exogenous foliage whey application. Journal of Plant Stress Physiology 5: 08-14.

Rocha, G.T., Silva, A.G. da, Martins, J.B., Peixoto, N., Rodrigues, F. 2019. Propagação vegetativa de Spondias tuberosa e Spondias dulcis com o uso de imersão em ácido indol acético. Revista Caatinga 32: 858-866.

Santana, D.G., Ranal, M.A. 2004. Análise da germinação: um enfoque estatístico. Editora Universidade de Brasília, Brasília, Brazil. 248 p.

Taiz, L., Zeiger, E., Moller, I. M., Murphy, A. 2017. Fisiologia e desenvolvimento vegetal. 6.ed. ArtMed, Porto Alegre, Brazil. 954 p.

Takata, W., Silva, E.G.D., Corsato, J.M., Ferreira, G. 2014. Germinação de sementes de romäzeiras (Punica granatum L.) de acordo com a concentração de giberelina. Revista Brasileira de Fruticultura 36: 254-260.

Conflict of Interest Statement: The authors declare that the research was conducted in the absence of any commercial or financial relationships that could be construed as a potential conflict of interest.

All the contents of this journal, except where otherwise noted, is licensed under a Creative Commons Attribution License attribuition-type BY. 